\title{
Stable isotope analysis reveals habitat partitioning among marine mammals off the NW African coast and unique trophic niches for two globally threatened species
}

\author{
A. M. Pinela*, A. Borrell, L. Cardona, A. Aguilar \\ Department of Animal Biology, Faculty of Biology and Biodiversity Research Institute, University of Barcelona, \\ 08028 Barcelona, Spain
}

\begin{abstract}
Stable isotope abundances of carbon $\left(\delta^{13} \mathrm{C}\right)$ and nitrogen $\left(\delta^{15} \mathrm{~N}\right)$ in the bone of 13 species of marine mammals from the northwest coast of Africa were investigated to assess their positions in the local trophic web and their preferred habitats. Also, samples of primary producers and potential prey species from the study area were collected to characterise the local isotopic landscape. This characterisation indicated that $\delta^{13} \mathrm{C}$ values increased from offshore to nearshore and that $\delta^{15} \mathrm{~N}$ was a good proxy for trophic level. Therefore, the most coastal species were Monachus monachus and Sousa teuszii, whereas the most pelagic were Physeter macrocephalus and Balaenoptera acutorostrata. $\delta^{15} \mathrm{~N}$ values indicated that marine mammals located at the lowest trophic level were $B$. acutorostrata, Stenella coeruleoalba and Delphinus sp., and those occupying the highest trophic level were M. monachus and P. macrocephalus. The trophic level of Orcinus orca was similar to that of $M$. monachus, suggesting that $O$. orca preys on fish. Conservation of coastal and threatened species (M. monachus and $S$. teuszii) off NW Africa should be a priority because these species, as the main apex predators, cannot be replaced by other marine mammals.
\end{abstract}

KEY WORDS: Marine mammals $\cdot$ Stable isotopes $\cdot$ Trophic ecology $\cdot$ Habitat use $\cdot$ NW Africa

\section{INTRODUCTION}

Exploitation of marine ecosystems is causing a rapid depletion of top predators worldwide (Pauly et al. 1998a, Jackson \& Sala 2001, Myers \& Worm 2003) and, as a result, marine food webs are undergoing extraordinary changes in their structure and function (Jackson et al. 2001, Emslie \& Patterson 2007). Fisheries are replacing apex predators in most marine food webs and exercise a formidable top-down control on these predators, but major differences in the behaviour of fisheries and that of marine apex predators (Trites et al. 2006) make intensely exploited ecosystems highly fluctuant (Anderson et al. 2008). An ecosystem-based management system has been advocated to avoid these problems, but this approach is often hindered by a poor knowledge of the basic biological traits of most apex predators.

The waters of the NW coast of Africa are among the most productive in the world (Ferreira 1978, Feidi 1996). In these waters, 2 important currents meet - the cold Canary Current and the warm Guinea Currentgenerating a quasi-permanent upwelling zone that triggers a high biological productivity (Wells \& Bleakley 1995, Longhurst 1998, Shumway 1999). Such productivity supports a highly diverse and abundant fauna of marine mammals, (Marchessaux \& Campredon 1988, Robineau \& Vely 1998, Nieri et al. 1999) which typically include, given the mix of waters, boreal species as well as tropical or subtropical species (Robineau \& Vely 1998). Additionally, the region shelters the last remnant populations of some scarce or highly endangered spe- 
cies, such as the Mediterranean monk seal Monachus monachus (González et al. 1997), the Atlantic humpback dolphin Sousa teuszii (Van Waerebeek et al. 2004) and the African manatee Trichechus senegalensis (Padial \& Ibáñez 2005). Mauritania is one of the major African fishing nations and has developed, alongside traditional artisanal fishing, industrial fisheries, becoming one of the major fish exporting African countries (Ababouch 2000). Overfishing, overcapacity, habitat degradation and inequitable access agreements have contributed to the decline in catches throughout West Africa (Atta-Mills et al. 2004, ter Hofstede \& DickeyCollas 2006). Assessing the impact of fisheries on the local ecosystem is of great interest (Jouffre \& Inejih 2005) but no studies have been conducted involving marine mammals.

Available information on the marine mammals of the region is limited to stranding and sighting reports in the case of cetaceans (Duguy 1976, Maigret 1980a,b, 1981, Marchessaux \& Campredon 1988, Van Waerebeek et al. 1999), although a few demographic parameters are known for Monachus monachus (González et al. 1997, Gazo et al. 2000). Nevertheless, the trophic relationships among the marine apex predators of the region have never been investigated, and their possible interactions with the fisheries operating in the area are largely unknown.

The methods traditionally used in the study of the trophic ecology of marine mammals have been faecal or stomach-content analyses. These methods present limitations because they only show recently eaten prey, and results can be severely biased owing to differences in prey digestion (Hobson et al. 1996). Conversely, stable isotope analysis offers an integrated measure of all prey assimilated over a comparatively protracted period of time (Tieszen et al. 1983, Michener \& Schell 1994, Hobson 1999). In marine mammals, stable isotopes of carbon and nitrogen have been extensively used to investigate the trophic ecology of populations (e.g. Hobson et al. 1997, Lesage et al. 2001, Drago et al. 2009). The relative abundance of heavy to light carbon isotopes $\left(\delta^{13} \mathrm{C}\right)$ has been used to discriminate between habitats where phytoplankton is the only source of organic carbon (pelagic and offshore habitats) and those where macrophytes are a relevant source of organic carbon (vegetated onshore benthic habitats) (Rubenstein \& Hobson 2004, Fry 2006, Cardona et al. 2007). By contrast, the relative abundance of heavy to light nitrogen isotopes $\left(\delta^{15} \mathrm{~N}\right)$ is commonly taken as an indicator of trophic level (Cabana \& Rasmussen 1996) because this abundance increases from prey to predator owing to the preferential excretion of the light isotope (Caut et al. 2009).

In the present study, stable isotope profiles of carbon and nitrogen were used to investigate the habitat use and trophic level of the marine mammals occurring in the waters off the northwest coast of Africa to determine their positions in the marine food web.

\section{MATERIALS AND METHODS}

Study site and sampling. The study was conducted in the Islamic Republic of Mauritania, located in the northwest region of Africa. Its coastline extends latitudinally more than $700 \mathrm{~km}$ from Cape Blanc to the Senegal River (Fig. 1). The northern part of the coast is composed of rocky cliffs with scattered small, tidedependent and sandy beaches (Habitat 1, Fig. 1); the intermediate region consists of tidal mudflats inhabited by the seagrass Halodule wrighti and Zostera noltii and shallow waters that extend several kilometres offshore, supporting dense sublittoral meadows of the seagrass Cymodocea nodosa with scattered deep unvegetated water channels in between (Parc National du Banc d'Arguin, Habitat 2, Fig. 1); and the southern region is a nearly continuous sandy beach with scattered sublittoral patches of the seagrass Cymodocea nodosa (La Grand Plage, Habitat 3, Fig. 1). Despite this heterogeneity, there are no major differences among the 3 regions in the distribution of the potential prey for marine mammals, whose abundance depends mainly on the depth of the coastal waters and the variation in sea surface temperature related to upwelling (ter Hofstede \& Dickey-Collas 2006).

Bone samples from 13 species of marine mammals (243 individuals; Table 1) were collected opportunistically between 1990 and 2008 along the Mauritanian coastline. Except for Monachus monachus, for which all samples came from natural mortalities, we have no information on the cause of death of the marine mammals used in this study. Bone was selected because, owing to its low turnover rate, it is possible to elucidate several years of dietary history (Hobson \& Clark 1992). The bone collected from each skull was a small fragment of turbinate bones from the nasal cavity because this fragment is easy to crush and its sampling did not damage the skull for subsequent studies. Furthermore, samples from 7 species of potential prey (fish and cephalopods), 1 species of sea turtle, 7 species of benthic macrophytes (benthic primary producers) and phytoplankton (pelagic primary producers) were also collected to characterise the isotopic landscape off the coast of Mauritania (Table 1).

The samples of leaf and thallus collected from seagrass and macroalgae, respectively, were dried with sodium chloride; and fish dorsal white muscle, cephalopod mantle and turtle muscle were stored in a freezer at $-20^{\circ} \mathrm{C}$ until analysis. Samples of skull and other bone tissues were stored without preservatives at 


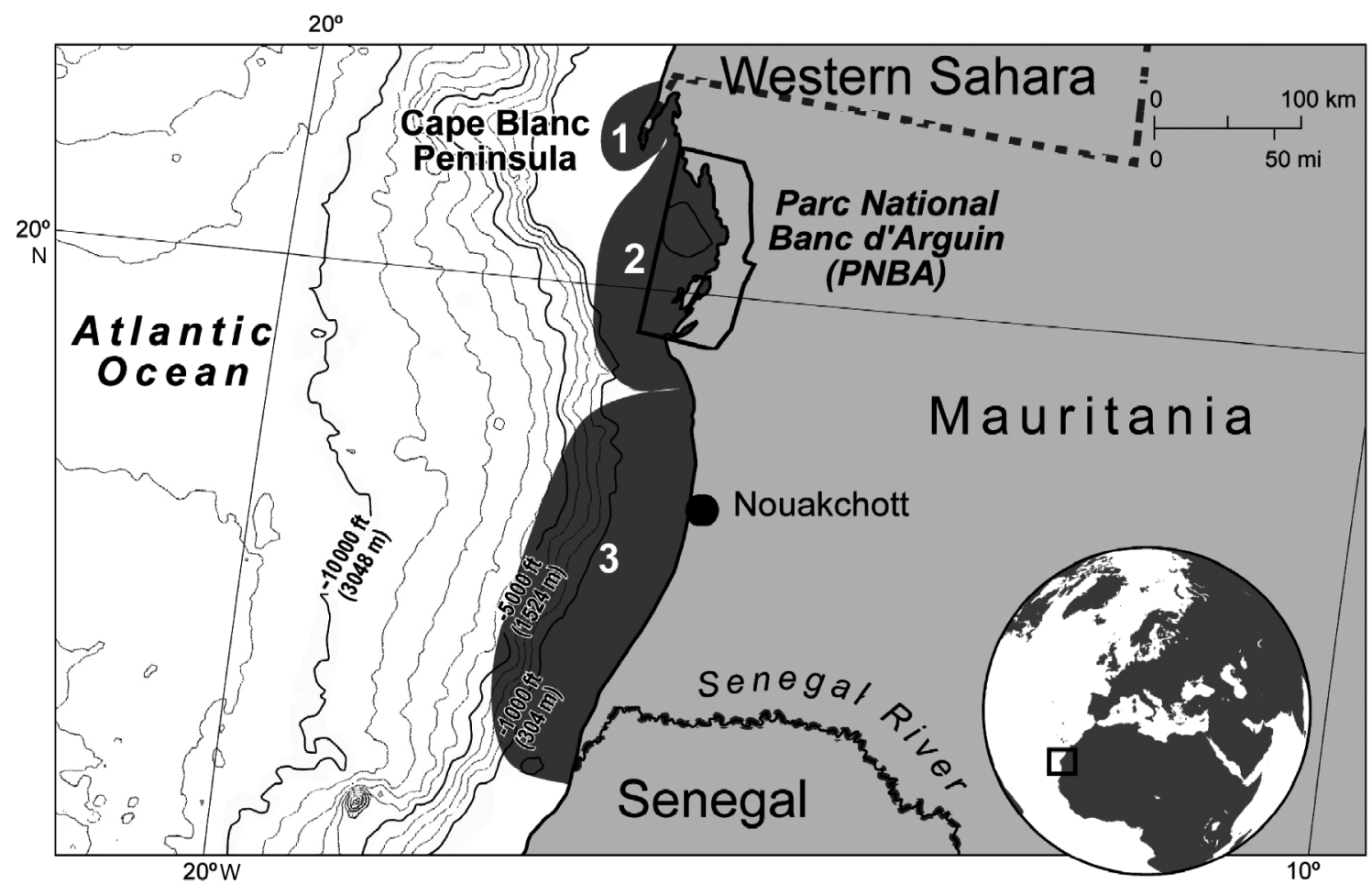

Fig. 1. Study area, with bathymetry, the overline of the continental shelf and the 3 main habitat types, indicated by dark grey areas with numbers (see 'Materials and methods' for habitat characterisation)

ambient temperature $\left(15\right.$ to $\left.25^{\circ} \mathrm{C}\right)$. Phytoplankton (whole organisms in collective samples) was refrigerated at $4^{\circ} \mathrm{C}$, brought to the laboratory, filtered in a precombusted GF/C filter and processed for isotopic determination.

Stable isotope analyses. Stable isotope abundances (expressed as delta notation, $\delta$ ), in which the relative variations of stable isotope ratios are expressed in per mille (\%) deviations from predefined international standards, were calculated as:

$$
\delta X=\left[\left(R_{\text {sample }} / R_{\text {standard }}\right)-1\right] \times 10^{3}
$$

where $X$ is the value of the heavy isotope of the sample $\left({ }^{13} \mathrm{C}\right.$ or $\left.{ }^{15} \mathrm{~N}\right), R_{\text {sample }}$ is the ratio of the heavy to the light isotope of the sample $\left({ }^{13} \mathrm{C} /{ }^{12} \mathrm{C}\right.$ or $\left.{ }^{15} \mathrm{~N} /{ }^{14} \mathrm{~N}\right)$ and $R_{\text {standard }}$ is the ratio of the heavy to the light isotope in the referenıce standards, which were Vienna Pee Dee Belemnite calcium carbonate for carbon and atmospheric nitrogen (air) for nitrogen.

For the pre-treatment of the samples, $\sim 1 \mathrm{~g}$ of tissue was rinsed with distilled water, dried for $3 \mathrm{~d}$ at $60^{\circ} \mathrm{C}$ and powdered with a mortar and pestle. Because lipids are depleted for ${ }^{13} \mathrm{C}$ compared with other molecules, and thus can mislead the analyses by decreasing the $\delta^{13} \mathrm{C}$ signal (DeNiro \& Epstein 1977), they were removed from the samples by rinsing the powdered tissue several times with a 2:1 chloroform:methanol solu- tion (Bligh \& Dyer 1959). When conducting stable isotope analysis in bone, several authors have carried out preventive demineralisation of the tissue by treating it with either a 0.5 or $1 \mathrm{M}$ hydrochloric acid $(\mathrm{HCl})$ solution (Bocherens et al. 1997, Newsome et al. 2006). However, a test using a subset of the samples $(n=20)$ revealed that $\delta^{13} \mathrm{C}$ and $\delta^{15} \mathrm{~N}$ values did not differ between demineralised and untreated samples, so this procedure was not followed. However, seagrass and macroalgae were treated with a $0.5 \mathrm{M} \mathrm{HCl}$ solution to eliminate inorganic carbonates that could bias the results ( $\mathrm{Ng}$ et al. 2007). Phytoplankton was also treated with $0.05 \mathrm{M} \mathrm{HCl}$ to remove carbonates following the protocol of Ogawa \& Ogura (1997). Some authors agree that it is possible that $\mathrm{HCl}$ treatment adversely affects the nitrogen isotopic signature (Bunn et al. 1995), thus primary producer samples (seagrass, macroalgae and collective phytoplankton samples) were separated into 2 subsamples used for carbon (after the $\mathrm{HCl}$ treatment) and for nitrogen (without the $\mathrm{HCl}$ treatment).

Finally, $1 \mathrm{mg}$ of bone, $0.5 \mathrm{mg}$ of white muscle from fish and of mantle from cephalopods, $4 \mathrm{mg}$ of homogenised seagrass and of macroalgae and $12 \mathrm{mg}$ of the homogenised phytoplankton with filter were weighed in tin capsules $(3.3 \times 5 \mathrm{~mm})$, combusted at $900^{\circ} \mathrm{C}$ and analysed in a continuous flow isotope ratio mass spec- 
Table 1. $\delta^{13} \mathrm{C}$ and $\delta^{15} \mathrm{~N}$ isotope values of each species collected along the Mauritanian coast. Data are given as means \pm SD $(\%)$, minimum and maximum isotope values, identification codes (ID code) and number of individuals per species (N). Bold values represent means $\pm \mathrm{SD}(\%)$, and minimum and maximum isotope values for each category

\begin{tabular}{|c|c|c|c|c|c|c|c|c|}
\hline \multirow[t]{2}{*}{ Species } & \multirow[t]{2}{*}{ ID code } & \multirow[t]{2}{*}{$\mathrm{N}$} & \multicolumn{3}{|c|}{$\longrightarrow \delta^{13} \mathrm{C} \longrightarrow$} & \multicolumn{3}{|c|}{$-\delta^{15} \mathrm{~N}(\% \circ)$} \\
\hline & & & Mean \pm SD & Min. & Max. & Mean \pm SD & Min. & Max. \\
\hline \multicolumn{9}{|l|}{ Pelagic primary producers } \\
\hline Phytoplankton & PHYTO & 3 & $-24.4 \pm 3.5$ & -26.9 & -20.3 & $8.9 \pm 0.3$ & 8.6 & 9.2 \\
\hline Benthic primary producers & & 34 & $-14.6 \pm 0.8$ & -19.9 & -5.3 & $3.8 \pm 0.18$ & 1.8 & 5.8 \\
\hline \multicolumn{9}{|l|}{ Seagrass } \\
\hline Cymodocea nodosa & CNOD & 5 & $-6.3 \pm 1.1$ & -7.5 & -5.3 & $2.6 \pm 0.8$ & 1.8 & 3.8 \\
\hline Halodule wrightii & HWRI & 5 & $-11.8 \pm 0.8$ & -13.0 & -10.7 & $4.3 \pm 1.1$ & 2.8 & 5.8 \\
\hline Zostera noltii & ZNOL & 5 & $-10.5 \pm 1.3$ & -7.5 & -5.3 & $2.9 \pm 0.2$ & 2.7 & 3.2 \\
\hline \multicolumn{9}{|l|}{ Macroalgae } \\
\hline Asparagopsis sp. & ASPA & 2 & $-19.7 \pm 0.4$ & -19.9 & -19.4 & $3.7 \pm 0.5$ & 3.3 & 4.1 \\
\hline Dictyota sp. & DICT & 5 & $-18.8 \pm 0.2$ & -19.1 & -18.7 & $4.7 \pm 0.4$ & 4.3 & 5.3 \\
\hline Padina sp. & PADI & 2 & $-16.1 \pm 1.3$ & -17.0 & -15.2 & $3.4 \pm 0.9$ & 2.7 & 4.0 \\
\hline Polysiphonia sp. & POLY & 5 & $-19.6 \pm 0.2$ & -19.9 & -19.4 & $3.6 \pm 0.4$ & 3.2 & 4.1 \\
\hline Sargassum sp. & SARG & 5 & $-17.7 \pm 0.2$ & -17.9 & -17.5 & $5.1 \pm 0.4$ & 4.4 & 5.4 \\
\hline Fish & & 43 & $-15.4 \pm 0.91$ & -18.0 & -14.1 & $13.1 \pm 1.73$ & 9.7 & 16.0 \\
\hline Caranx rhonchus & CRHO & 11 & $-14.8 \pm 0.29$ & -15.5 & -14.4 & $14.1 \pm 0.50$ & 13.5 & 14.8 \\
\hline Mullus barbatus & MBAR & 10 & $-16.2 \pm 0.77$ & -17.5 & -15.0 & $13.1 \pm 0.83$ & 11.6 & 14.2 \\
\hline Pagellus bellotii & PBEL & 9 & $-15.7 \pm 1.25$ & -18.0 & -14.2 & $14.3 \pm 1.07$ & 13.0 & 16.0 \\
\hline Plectorhinchus mediterraneus & PMED & 1 & -14.1 & & & 14.2 & & \\
\hline Sardinella aurita & SAUR & 10 & $-15.0 \pm 0.39$ & -15.7 & -14.3 & $10.4 \pm 0.66$ & 9.7 & 11.0 \\
\hline Scomberomorus tritor & STRI & 2 & $-15.7 \pm 0.21$ & -15.8 & -15.5 & $14.1 \pm 0.32$ & 14.0 & 14.4 \\
\hline \multicolumn{9}{|l|}{ Cephalopods } \\
\hline Loligo sp. & LOLI & 1 & -15.1 & & & 14.4 & & \\
\hline \multicolumn{9}{|l|}{ Marine turtles } \\
\hline Chelonia mydas & CMID & 4 & $-9.3 \pm 2.2$ & -11.6 & -6.8 & $7.8 \pm 1.2$ & 6.0 & 8.6 \\
\hline Marine mammals & & 243 & $-11.7 \pm 1.23$ & -15.9 & -8.1 & $13.4 \pm 1.16$ & 10.8 & 17.1 \\
\hline Balaenoptera acutorostrata & BACU & 1 & -15.9 & & & 11.8 & & \\
\hline Delphinus sp. & DDEL & 95 & $-12.4 \pm 0.81$ & -15.3 & -9.7 & $12.7 \pm 0.83$ & 10.8 & 15.9 \\
\hline Globicephala macrorhynchus & GMAC & 9 & $-11.5 \pm 0.53$ & -12.5 & -10.7 & $14.0 \pm 0.39$ & 13.5 & 14.6 \\
\hline Globicephala melas & GMEL & 2 & $-11.1 \pm 0.42$ & -11.4 & -10.8 & $14.1 \pm 0.27$ & 13.9 & 14.3 \\
\hline Grampus griseus & GGRI & 1 & -12.0 & & & 13.8 & & \\
\hline Monachus monachus & MMON & 12 & $-10.4 \pm 0.63$ & -11.2 & -8.9 & $14.5 \pm 0.70$ & 12.9 & 15.4 \\
\hline Orcinus orca & ORCA & 3 & $-11.9 \pm 1.39$ & -13.2 & -10.4 & $14.5 \pm 0.52$ & 14.0 & 15.0 \\
\hline Phocoena phocoena & PPHO & 42 & $-11.7 \pm 0.94$ & -14.0 & -9.7 & $13.6 \pm 0.76$ & 11.6 & 15.4 \\
\hline Physeter macrocephalus & PMAC & 2 & $-13.9 \pm 2.11$ & -15.4 & -12.4 & $15.9 \pm 0.06$ & 15.9 & 16.0 \\
\hline Sousa teuszii & STEU & 11 & $-9.7 \pm 0.93$ & -11.5 & -8.1 & $13.3 \pm 1.33$ & 11.7 & 15.3 \\
\hline Stenella coeruleoalba & SCOE & 1 & -12.0 & & & 11.9 & & \\
\hline Stenella frontalis & SFRO & 4 & $-12.1 \pm 0.30$ & -12.4 & -11.8 & $13.2 \pm 1.02$ & 12.3 & 14.6 \\
\hline Tursiops truncatus & TTRU & 60 & $-11.1 \pm 1.23$ & -15.4 & -8.3 & $13.9 \pm 1.30$ & 11.4 & 17.1 \\
\hline
\end{tabular}

trometer (Flash 1112 IRMS Delta C Series EA, Thermo Finnigan, Bremen, Germany). Atropine was used as a standard to check the elemental composition for carbon and nitrogen. International isotope secondary standards of known ${ }^{13} \mathrm{C} /{ }^{12} \mathrm{C}$ ratios, as given by the IAEA (International Atomic Energy Agency)namely, polyethylene (IAEA $\mathrm{CH7}, \delta^{13} \mathrm{C}=-31.8 \%$ ), graphite (USGS24, $\delta^{13} \mathrm{C}=-16.1 \%$ ) and sucrose (IAEA $\mathrm{CH} 6, \delta^{13} \mathrm{C}=-10.4 \%$ o) - were used for calibration at a precision of $0.2 \%$. For nitrogen, international isotope secondary standards of known ${ }^{15} \mathrm{~N} /{ }^{14} \mathrm{~N}$ ratiosnamely, $\left(\mathrm{NH}_{4}\right)_{2} \mathrm{SO}_{4}$ (IAEA N1, $\delta^{15} \mathrm{~N}=+0.4 \%$ and IAEA $\mathrm{N} 2, \delta^{15} \mathrm{~N}=+20.3 \%$ ) and $\mathrm{KNO}_{3}$ (IAEA $\mathrm{NO}_{3}, \delta^{15} \mathrm{~N}=$ $+4.7 \%$ o - were used for calibration at a precision of $0.3 \%$.
Data analyses. The assumption of normality in the distributions of the sample groups was checked with the Kolmogorov-Smirnov test. The assumption of homogeneity of variances between sample groups was checked with Levene's test.

Differences in mean bivariated isotope ratios $\left(\delta^{13} \mathrm{C}\right.$ and $\delta^{15} \mathrm{~N}$ ) among marine mammal species were assessed using a multivariate analysis of variance (MANOVA) because they displayed a normal distribution. Univariate ANOVA was conducted separately for both isotopes. If a statistical significant interaction was found between marine mammal species for $\delta^{13} \mathrm{C}$ and $\delta^{15} \mathrm{~N}$ using an ANOVA, additional pairwise comparisons were made using a generalised linear model because it admits data that do not meet the assumption 
of homogeneity of variance. Post hoc analyses were made by means of least significant differences (LSD) tests based on estimated marginal means. As a method of estimation, the maximum likelihood (ML) was used in all cases. Normality distributions and identity as a link function were always used (for both $\delta^{13} \mathrm{C}$ and $\delta^{15} \mathrm{~N}$ ), because data followed a normal distribution. Goodness of fit values (Akaike's information criterion, AIC) were used to compare different models. The confidence interval level was set at 95\% for all comparisons. The post hoc pairwise comparison by generalised linear model is a more flexible and less conservative statistical tool than the post hoc pairwise comparison by general linear model because several types of distribution and models can be chosen to fit the data. The post hoc test was conducted for the species represented by more than one sample (Stenella coeruleoalba, Grampus griseus and Balaenoptera acutorostrata were excluded from the analysis).

Unless otherwise stated, data are presented as means \pm standard deviation (SD) throughout the man- uscript, except when a species is represented by a single individual. All the statistical analyses were conducted using the SPSS ver.15.

\section{RESULTS}

\section{The isotopic landscape}

Macroalgae presented lower $\delta^{13} \mathrm{C}$ values in comparison with seagrass but presented higher $\delta^{13} \mathrm{C}$ values in comparison with phytoplankton (Fig. 2, Table 1). The $\delta^{13} \mathrm{C}$ value of green turtles was close to that of the seagrass that they consume (Cardona et al. 2009), whereas the $\delta^{13} \mathrm{C}$ of fish and cephalopods were between those of phytoplankton and benthic primary producers. As expected, coastal fish (Plectorhinchus mediterraneus, Caranx rhonchus and Sardinella aurita) displayed higher $\delta^{13} \mathrm{C}$ values than did more offshore species (Pagellus bellotii, Scomberomorus tritor and Mullus barbatus), but none of the sampled species

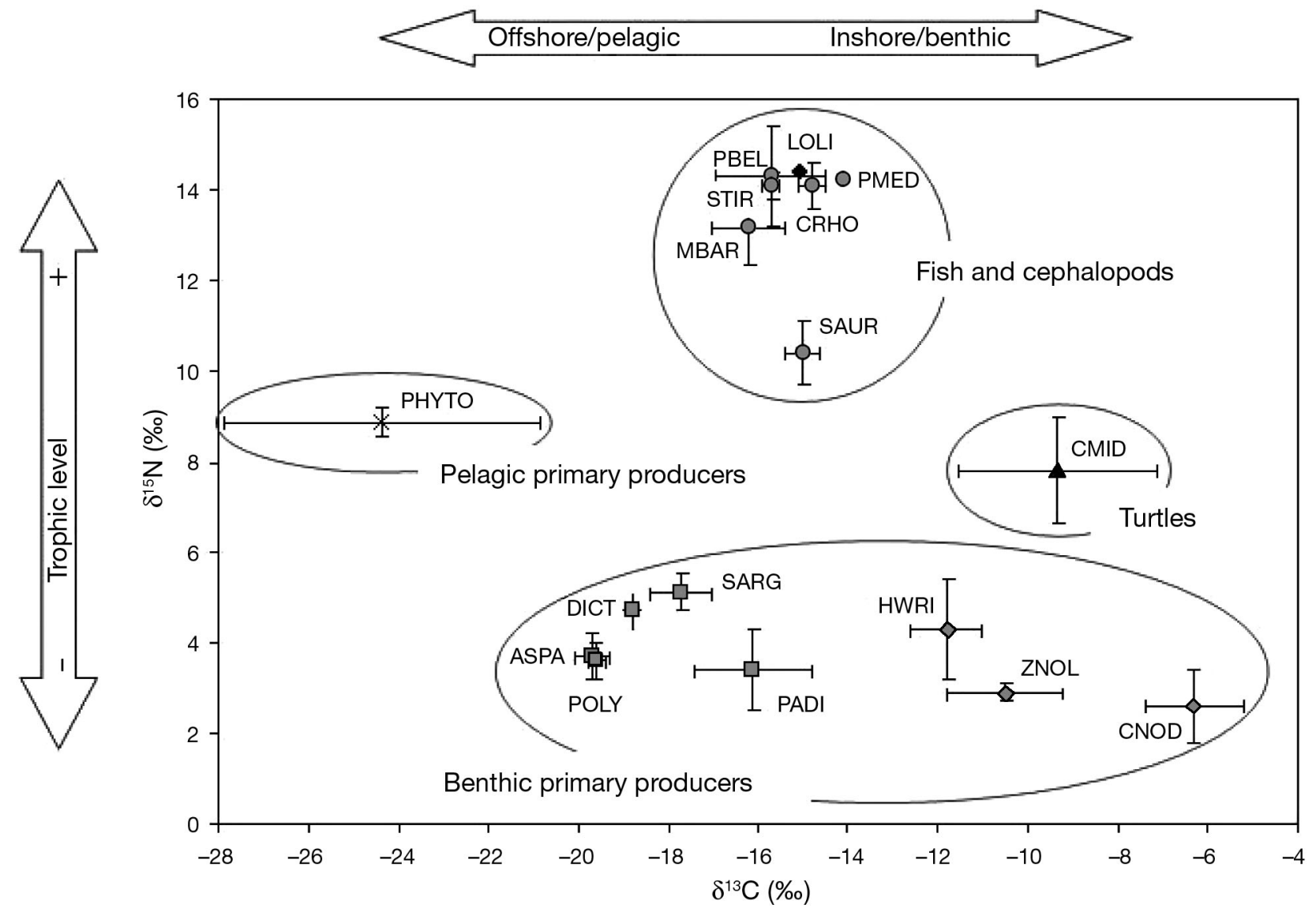

Fig. 2. Mean $( \pm \mathrm{SD}, \%) \delta^{13} \mathrm{C}$ and $\delta^{15} \mathrm{~N}$ isotope values for all trophic groups considered, except marine mammals: phytoplankton $(\times)$, seagrass $(\diamond)$, macroalgae $(\square)$, fish $(\bullet)$, cephalopods $(\bullet)$ and sea turtle $(\boldsymbol{\Delta})$. The identification codes and number of individuals for each species are presented in Table 1; ellipses enclose groups listed in Table 1 
was truly oceanic. The $\delta^{15} \mathrm{~N}$ of macrophytes was highly variable and ranged from 2.6\% (the seagrass Сymodocea nodosa) to $5.4 \%$ (the macroalgae Sargassum sp.). Phytoplankton displayed higher $\delta^{15} \mathrm{~N}$ values than did any benthic macrophyte. As expected, green turtles were more enriched for $\delta^{15} \mathrm{~N}$ than were benthic primary producers, and the zooplanktophagous fish $S$. aurita was more enriched for $\delta^{15} \mathrm{~N}$ than was phytoplankton. Likewise, fish including only small invertebrates in their diets ( $M$. barbatus and $S$. aurita) presented lower $\delta^{15} \mathrm{~N}$ values when compared with fish consuming large invertebrates and fish (C. rhonchus, $S$. tritor and P. mediterraneus). Such an isotopic landscape indicates that the bone of oceanic marine mammals should present lower $\delta^{13} \mathrm{C}$ values than that of coastal marine mammals, especially those inhabiting seagrass meadows. Furthermore, $\delta^{15} \mathrm{~N}$ is a good proxy for trophic level in the considered system, although species inhabiting seagrass meadows might present lower $\delta^{15} \mathrm{~N}$ values in comparison with oceanic species at the same trophic level.
As revealed by the $\delta^{13} \mathrm{C}$ values, 4 major groups of marine mammals exist as delineated by their distribution along the coastal-oceanic axis (Fig. 3). Carbon isotope values together with the results of the post hoc pairwise comparisons allowed us to group species according to the similarity of their $\delta^{13} \mathrm{C}$ values. The most coastal group, characterised by values of the $\delta^{13} \mathrm{C}$ close to those of seagrass, included Monachus monachus $\left(\delta^{13} \mathrm{C}=-10.4 \%\right)$ and Sousa teuszii $\left(\delta^{13} \mathrm{C}=-9.7 \%\right)$. The most oceanic group, characterised by highly negative $\delta^{13} \mathrm{C}$ values, included Physeter macrocephalus $\left(\delta^{13} \mathrm{C}=-13.9 \%\right)$. Balaenoptera acutorostrata $\left(\delta^{13} \mathrm{C}=\right.$ $-15.9 \%$ ) probably belonged to this group, although only one individual was sampled. The remaining 9 species had $\delta^{13} \mathrm{C}$ values between these 2 groups, with Delphinus sp., Globicephala macrorhynchus, Phocoena phocoena, Stenella frontalis and Orcinus orca presenting lower $\delta^{13} \mathrm{C}$ values than Globicephala melas and Tursiops truncatus (Table 1, Fig. 3).

Regarding the $\delta^{15} \mathrm{~N}$ values, significant differences were observed between the most $\delta^{15} \mathrm{~N}$-enriched spe-

\section{Stable isotopic composition of marine mammals}

Statistically significant differences exist among the bivariated isotopic signals of the considered species of marine mammals (MANOVA test, Wilk's lamb$\mathrm{da}=0.413, F=14.131, \mathrm{p}<0.001)$. ANOVA indicated that both nitrogen and carbon were involved in these differences $\left(\delta^{13} \mathrm{C}: F=16.982, \mathrm{p}<0.001\right.$; $\delta^{15} \mathrm{~N}: F=11.256, \mathrm{p}<0.001$; Table 2). The results of the post hoc test for pairwise comparisons between species for $\delta^{13} \mathrm{C}$ and $\delta^{15} \mathrm{~N}$ are illustrated in Table 3.
Table 2. Summary of the results of the ANOVA to test for differences in the $\delta^{13} \mathrm{C}$ and $\delta^{15} \mathrm{~N}$ values of the marine mammal species investigated in the study area

\begin{tabular}{|lrrrrrr|}
\hline Factor & \multicolumn{1}{c}{$\mathrm{SS}$} & $\mathrm{df}$ & \multicolumn{1}{c}{$\mathrm{MS}$} & \multicolumn{1}{c|}{$F$} & $\mathrm{p}$ & $\mathrm{r}^{2}$ \\
\hline$\delta^{13} \mathrm{C}(\%)$ & & & & & & \\
Model & 140.791 & 9 & 15.643 & 16.982 & $<0.001$ & 0.399 \\
Intercept & 7009.343 & 1 & 7009.343 & 7608.979 & $<0.001$ & \\
Species & 140.791 & 9 & 15.643 & 16.982 & $<0.001$ & \\
Error & 211.875 & 230 & 0.921 & & & \\
Total & 33183.103 & 240 & & & & \\
& & & & & & \\
$\delta^{15} \mathrm{~N}(\%)$ & & & & & & \\
Model & 94.977 & 9 & 10.553 & 11.256 & $<0.001$ & 0.306 \\
Intercept & 10178.900 & 1 & 10178.900 & 10857.200 & $<0.001$ & \\
Species & 94.977 & 9 & 10.553 & 11.256 & $<0.001$ & \\
Error & 215.631 & 230 & 0.938 & & & \\
Total & 43505.029 & 240 & & & & \\
\hline
\end{tabular}

Table 3. Results of the post hoc test for multiple comparisons between the marine mammal species collected along the Mauritanian coast (see Table 1 for codes). Carbon isotope $\left(\delta^{13} \mathrm{C}\right) \mathrm{p}$-values are reported below the diagonal and those for nitrogen isotopes $\left(\delta^{15} \mathrm{~N}\right)$ are reported above the diagonal. Significant $\mathrm{p}$-values $(<0.05)$ are highlighted in bold

\begin{tabular}{lcccccccccc|}
\hline & DDEL & GMAC & MMON & PPHO & STEU & TTRU & SFRO & GMEL & ORCA & PMAC \\
\hline DDEL & & $\mathbf{0 . 0 0 0}$ & $\mathbf{0 . 0 0 0}$ & $\mathbf{0 . 0 0 0}$ & 0.052 & $\mathbf{0 . 0 0 0}$ & 0.334 & $\mathbf{0 . 0 4 9}$ & $\mathbf{0 . 0 0 2}$ & $\mathbf{0 . 0 0 0}$ \\
GMAC & $\mathbf{0 . 0 0 8}$ & & 0.271 & 0.259 & 0.104 & 0.778 & 0.154 & 0.940 & 0.458 & $\mathbf{0 . 0 0 9}$ \\
MMON & $\mathbf{0 . 0 0 0}$ & $\mathbf{0 . 0 0 8}$ & & $\mathbf{0 . 0 0 6}$ & $\mathbf{0 . 0 0 4}$ & 0.064 & $\mathbf{0 . 0 2 0}$ & 0.577 & 0.988 & $\mathbf{0 . 0 4 2}$ \\
PPHO & $\mathbf{0 . 0 0 0}$ & 0.523 & $\mathbf{0 . 0 0 0}$ & & 0.351 & 0.118 & 0.399 & 0.513 & 0.128 & $\mathbf{0 . 0 0 1}$ \\
STEU & $\mathbf{0 . 0 0 0}$ & $\mathbf{0 . 0 0 0}$ & 0.076 & $\mathbf{0 . 0 0 0}$ & & 0.055 & 0.829 & 0.305 & 0.060 & $\mathbf{0 . 0 0 0}$ \\
TTRU & $\mathbf{0 . 0 0 0}$ & 0.199 & $\mathbf{0 . 0 2 6}$ & $\mathbf{0 . 0 0 1}$ & $\mathbf{0 . 0 0 0}$ & & 0.143 & 0.825 & 0.314 & $\mathbf{0 . 0 0 3}$ \\
SFRO & 0.585 & 0.284 & $\mathbf{0 . 0 0 2}$ & 0.435 & $\mathbf{0 . 0 0 0}$ & $\mathbf{0 . 0 3 3}$ & & 0.291 & 0.077 & $\mathbf{0 . 0 0 1}$ \\
GMEL & 0.060 & 0.588 & 0.332 & 0.363 & 0.054 & 0.960 & 0.218 & 0.378 & 0.633 & $\mathbf{0 . 0 4 8}$ \\
ORCA & 0.357 & 0.567 & $\mathbf{0 . 0 1 7}$ & 0.805 & $\mathbf{0 . 0 0 0}$ & 0.155 & 0.732 & 0.378 & 0.091 \\
PMAC & $\mathbf{0 . 0 2 4}$ & $\mathbf{0 . 0 0 1}$ & $\mathbf{0 . 0 0 0}$ & $\mathbf{0 . 0 0 1}$ & $\mathbf{0 . 0 0 0}$ & $\mathbf{0 . 0 0 0}$ & $\mathbf{0 . 0 2 9}$ & $\mathbf{0 . 0 0 3}$ & $\mathbf{0 . 0 1 8}$ & \\
\hline
\end{tabular}




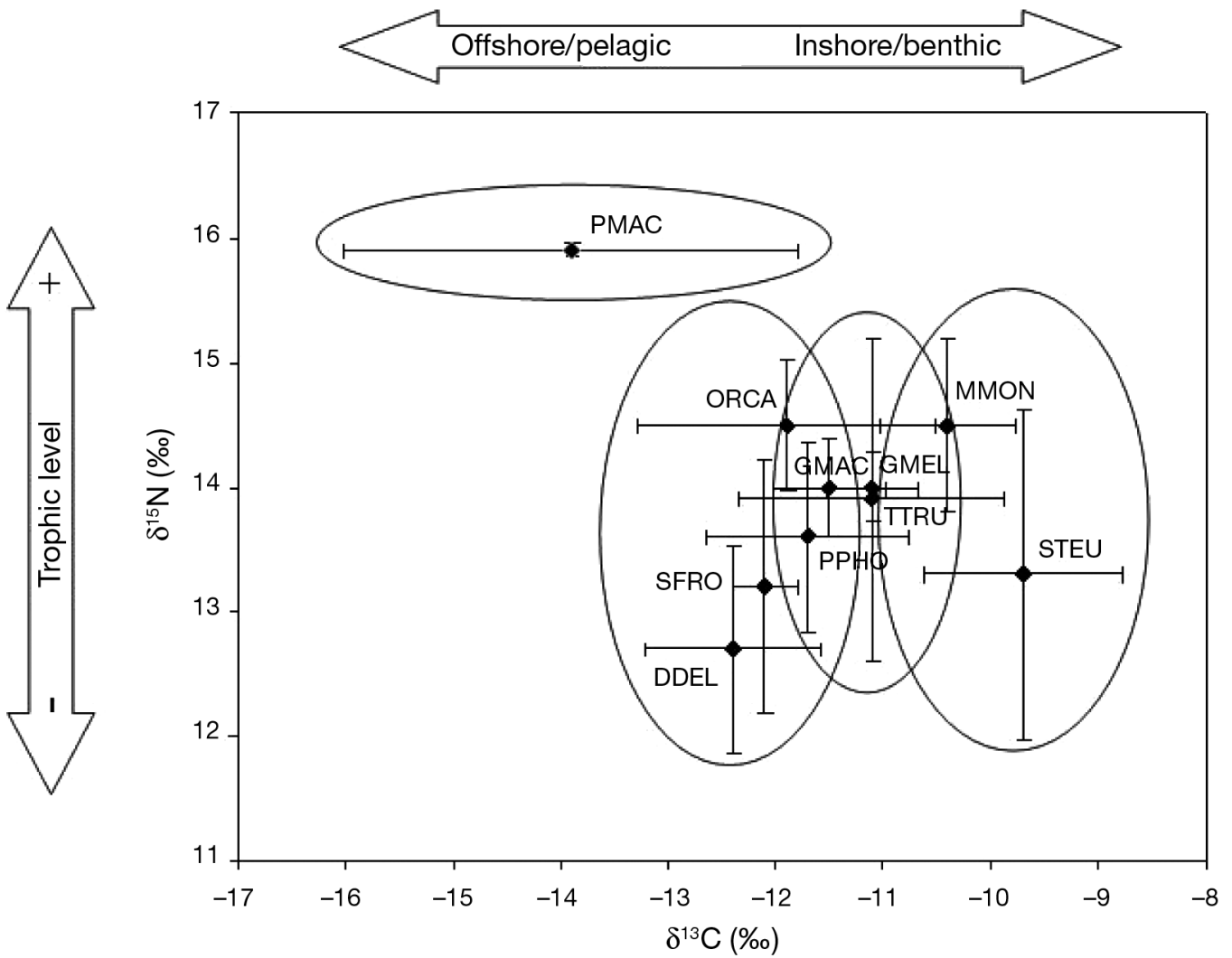

Fig. 3. Mean $( \pm \mathrm{SD}, \%) \delta^{13} \mathrm{C}$ and $\delta^{15} \mathrm{~N}$ isotope values of the marine mammal species collected in Mauritania. The identification codes and number of individuals for each species are presented in Table 1 ; ellipses group the species that did not display significant differences in $\delta^{13} \mathrm{C}$ values ( $\left.p>0.05\right)$

cies (Physeter macrocephalus) and those species less enriched (e.g. Delphinus sp. and Sousa teuszii; Tables 1 \& 3, Fig. 3). The only specimens of Balaenoptera acutorostrata and Stenella coeruleoalba analysed were also highly depleted for $\delta^{15} \mathrm{~N}-11.8$ and $11.9 \%$, respectively. Differences in $\delta^{15} \mathrm{~N}$ values among species revealed differences in trophic level: species with higher $\delta^{15} \mathrm{~N}$ values were at a higher trophic level than species with lower $\delta^{15} \mathrm{~N}$ values. However, as previously stated, coastal species might present lower $\delta^{15} \mathrm{~N}$ values in comparison with oceanic species at the same trophic level. Accordingly, P. macrocephalus was the species with the highest trophic level, while $B$. acutorostrata and $S$. coeruleoalba were the species with the lowest trophic levels. It is important to notice that the mean trophic level of Orcinus orca $\left(\delta^{15} \mathrm{~N}=14.5 \%\right.$ o) was equal to that of Monachus monachus $\left(\delta^{15} \mathrm{~N}=14.5 \%\right)$ and lower than that of P. macropehalus $\left(\delta^{15} \mathrm{~N}=15.9 \%\right)$. However, direct comparisons between species may be slightly biased owing to the fact that M. monachus is a much more coastal species than $O$. orca.

\section{DISCUSSION}

Although the use of stable isotopes as diet tracers is a powerful technique, interpretation of the results is not always straightforward because the method is more reliable when large differences exist between the isotopic signals of the considered sources. Many researchers do not assess the variability in $\delta^{15} \mathrm{~N}$ among primary producers because it is assumed that they have similar $\delta^{15} \mathrm{~N}$ values. Although this is true in some ecosystems and regions, exceptions are common (Drago et al. 2009). The present study reveals a high variability in $\delta^{15} \mathrm{~N}$ among macrophyte species from the same region and also between macrophytes and phytoplankton, with differences often larger than the average increase expected per trophic level (Minagawa \& Wada 1984, Caut et al. 2009). As a consequence, variability in the $\delta^{15} \mathrm{~N}$ of marine mammal bone may reflect not only differences in trophic level but also shifts among foraging grounds with primary producers that differ in $\delta^{15} \mathrm{~N}$ values. In the Mauritanian ecosystem, coastal marine mammals are expected to 
have lower $\delta^{15} \mathrm{~N}$ values than their oceanic counterparts because macrophytes display lower $\delta^{15} \mathrm{~N}$ values than particulate organic matter. In species feeding on a variety of prey species with different nitrogen baselines, diet composition is difficult to establish simply through stable isotope analysis of nitrogen. Fortunately, the $\delta^{13} \mathrm{C}$ of primary producers from Mauritania varied more consistently among groups, with phytoplankton less enriched in ${ }^{13} \mathrm{C}$ than macroalgae, and macroalgae less enriched in ${ }^{13} \mathrm{C}$ than seagrass. This allowed us to interpret the enrichment in ${ }^{13} \mathrm{C}$ of the bone of marine mammals as evidence of more-coastal foraging habitats.

Therefore, Sousa teuszii and Monachus monachus appear to be the most coastal species, a result consistent with published information about the distribution of these species off Mauritania. The main area of occurrence of $S$. teuszii is the Banc d'Arguin, a large system of shallow waters and channels extending along the northern coast of the country (Maigret et al. 1976, Maigret 1980a, Van Waerebeek et al. 2004). M. monachus is found off the Cape Blanc Peninsula, although it has also been observed to travel several miles offshore to obtain its prey (Gazo \& Aguilar 2005). Despite the similarity in the $\delta^{13} \mathrm{C}$ values of $M$. monachus and $S$. teuszii, the former was far more enriched for $\delta^{15} \mathrm{~N}$. This result is also consistent with stomachcontent analysis, as $S$. teuszii consumes primarily detritivorus and zooplanktophagous fish that are abundant nearshore (Cadenat \& Paraíso 1957, Van Waerebeek et al. 2004), whereas $M$. monachus principally eats lobsters, octopus and benthic, carnivorous fish (Marchessaux 1989). However, increasing fish landings have resulted in stocks, especially those of demersal fish and invertebrates (crustaceans and cephalopods), being overexploited or severely depleted (Christensen et al. 2004, Jouffre \& Inejih 2005), most likely affecting the feeding behaviour of $M$. monachus and $S$. teuszii.

Also, the $\delta^{13} \mathrm{C}$ values suggest that Balaenoptera acutorostrata and Physeter macrocephalus are the most oceanic species in the region; $B$. acutorostrata has been observed both in coastal and offshore waters off of the Western Sahara (Van Waerebeek et al. 1999). Distribution data for P. macrocephalus off Mauritania are limited (Maigret 1980b), although the species is oceanic over most of its range worldwide (Rendell et al. 2004). The diet of these species off NW Africa is unknown, but elsewhere $P$. macrocephalus preys mostly on large, oceanic squid with a high trophic level (Clarke et al. 1976, Pauly et al. 1998b, Ostrom et al. 1993, González et al. 1994), which is consistent with its high $\delta^{15} \mathrm{~N}$ in the study area. By contrast, B. acutorostrata primarily consumes schooling fish (Das et al. 2003, Hassani et al. 1997, Pauly et al. 1998b, MacLeod et al. 2007). This kind of prey could explain its semblance with $S$. coeru- leoalba with respect to $\delta^{15} \mathrm{~N}$ values, although only one specimen of the latter was analysed.

The remaining species lie between the former 2 groups, spaced along a continuous gradient. Tursiops truncatus is found in both coastal and offshore habitats along the Mauritanian coastline (Robineau \& Vely 1998). This probably explains the large intraspecific variability in the $\delta^{13} \mathrm{C}$ values and suggests the occurrence of persistent individual differences in foraging habits or even the existence of coastal versus offshore populations and/or ecotypes in the area, as has been found elsewhere (Segura et al. 2006).

Nevertheless, the mean $\delta^{13} \mathrm{C}$ value of Tursiops truncatus was close to that of Globicephala melas, a typical deepwater species in the North Atlantic (MacLeod et al. 2007) that is also known to occur over the continental shelf off Banc d'Arguin and off the Grande Plage (Maigret et al. 1976, Robineau \& Vely 1998). G. melas displayed a slightly higher $\delta^{13} \mathrm{C}$ value than Globicephala macrorhynchus, a species usually inhabiting deeper water over the upper slope in the North Atlantic (Davis et al. 2002), although nothing is known about its distribution off Mauritania. Finally, these 3 species presented lower $\delta^{13} \mathrm{C}$ values than those of Sousa teuszii and Monachus monachus and higher values than those of typical oceanic species, such as Delphinus sp. and Physeter macrocephalus (Robineau \& Vely 1998, Rendell et al. 2004). However, T. truncatus, G. melas and G. macrorhynchus also showed similar $\delta^{15} \mathrm{~N}$ values, suggesting that they possibly forage for similar prey. Published dietary data, only available for T. truncatus off Mauritania, identified the detritivorous grey mullet Mugil cephalus as their main prey item (Robineau \& Vely 1998). This observation does not seem to correlate with the typical prey of the 2 species of Globicephala (Overholtz \& Waring 1991). It is possible, however, that only a fraction of the population of T. truncatus regularly consumes grey mullet, while most of the population has a diet similar to that of Globicephala spp. This scenario has been reported, for instance for northern Spain, were G. melas and T. truncatus feed mainly on neritic cephalopods (González et al. 1994). Likewise, in the Gulf of California, the coastal ecotype of $T$. truncatus displayed values of the $\delta^{13} \mathrm{C}$ similar to those of coastal prey items such as the mullet $M$. cephalus, whereas the offshore ecotype of $T$. truncatus displayed values of the $\delta^{13} \mathrm{C}$ more similar to those of pelagic fish and medium-sized squid (Segura et al. 2006).

The species below the previous 3 in decreasing order of $\delta^{13} \mathrm{C}$ are Phocoena phocoena, Orcinus orca, and Grampus griseus. P. phocoena inhabits cold-temperate and subpolar regions in the North Atlantic, generally showing affinity for shelf waters (Skov et al. 1995). Mauritania is the southern limit of the distribution range of 
the species probably because of the coastal upwelling, which produces relatively cold waters (Smeenk et al. 1992). Sightings suggest that $P$. phocoena lives close to the coast in the non-upwelling season and moves offshore in the onset of the upwelling season (Marchessaux \& Campredon 1988, Smeenk et al. 1992, Robineau $\&$ Vely 1998). The diet of $P$. phocoena off NW Africa is unknown, but mean $\delta^{15} \mathrm{~N}$ values are similar to those of Tursiops truncatus, which is consistent with a fishbased diet (Fontaine et al. 1994). Orcinus orca has been reported in both coastal and oceanic areas off Mauritania, except in the very shallow waters of the Parc National du Banc d'Arguin (Duguy 1976, Maigret 1981). However, its $\delta^{13} \mathrm{C}$ values reveal a preference for the deeper parts of the continental shelf and the shelf break, as they are close to the values for Delphinus sp. The Mauritanian population of $O$. orca appears to be the 'offshore' ecotype, which is an ecotype thought to eat fish (Ford et al. 2000, Saulitis et al. 2000). This is in agreement with visual observations that suggested that $O$. orca avoided other marine mammals, including the monk seal M. monachus (A. Aguilar unpubl. data). The mean $\delta^{15} \mathrm{~N}$ of this species suggests a diet based on carnivorous fish, as reported for southern Spain (De Stephanis et al. 2008). Grampus griseus is poorly reported in NW Africa (Robineau \& Vely 1998), but isotopic values revealed an oceanic habitat preference that occurs seaward of the continental slope and is concentrated along the upper continental slope (Baumgartner 1997, Davis et al. 2002).

Delphinus sp. is seldom observed onshore in Mauritania (Robineau \& Vely 1998) and displays a typical oceanic behaviour. Stenella frontalis also typically inhabits the shelf break (Nieri et al. 1999) because the quasi-permanent upwelling may act as a thermal barrier and prevent it from approaching the inshore coastal zone (Robineau \& Vely 1998). Likewise, Stenella coeruleoalba is oceanic over most of its range (Aguilar 2000, Davis et al. 2002). Accordingly, these 3 species are more depleted for $\delta^{13} \mathrm{C}$ than Monachus monachus, Sousa teuszii and Tursiops truncatus. Delphinus sp. and $S$. coeruleoalba presented some of the lowest $\delta^{15} \mathrm{~N}$ values of all marine mammals, which is similar to what has been observed for other marine trophic webs (Das et al. 2003, Walker and Macko 1999). The discrepancies in $\delta^{15} \mathrm{~N}$ values of these species compared with that of other pelagic marine mammals possibly reflects the higher proportion of low-trophic-level prey, such as Sardinella aurita, in the diet of these species off the coast of Mauritania. Additionally, dolphins are opportunistic feeders and thus take advantage of the local abundance of prey (Hassani et al. 1997).

The results obtained in the present study suggest that the outer continental shelf and the upper slope are the areas with greater marine mammal species diver- sity. However, coastal areas are home to the most vulnerable and endangered species in the Mauritanian marine ecosystems. In the outer continental shelf and upper slope, there could be a certain redundancy between species because their isotopic signals are very similar, indicating that they occupy a very similar ecological niche. By contrast, the reduced number of species and the greater difference in isotopic signals indicate less redundancy in the coastal areas. From this point of view, conservation of coastal species (Monachus monachus and Sousa teuszii) in Mauritania should be a priority because, if these species were to disappear, they could not be replaced in the trophic web by other marine mammals. In the case of $M$. monachus, it is likely that this species is already extinct from the ecological point of view, given the small number of individuals of this population (Forcada et al. 1999). Artisanal fisheries could have an impact on $M$. monachus and $S$. teuszii, although industrial fishing operating in the deepest parts of the continental shelf are the only sources of incidental bycatch recorded to date in the region and Phoecoena phocoena and Stenella frontalis are the only species known to be affected (Nieri et al. 1999). Nevertheless, overfishing of the local demersal species by the intensive bottom trawling fishing in Mauritania (Jouffre \& Inejih 2005) may have limited the prey availability for $M$. monachus, which might explain, in part, the reproductive problems of this species (Pastor 2010). Therefore, the highest priority of conservation efforts should be to reduce the impact of artisanal and industrial bottom trawling fishing on the less abundant and most vulnerable species. Nonetheless, it will also be important to regularly estimate and control the populations and catches of fishes in the whole study area because this region shelters a great diversity of marine mammals. There are inevitable consequences of fishing down the food web: increased ecosystem instability, unsustainable fisheries and an inability for the ecosystem to support healthy, abundant populations of apex predators (Trites et al. 2006). Excessive catches of one species may lead to the collapse of an important predator or prey in the system, which may cause changes in the growth and survival patterns of other species in the food web (Walters \& Kitchell 2001). Some groups of apex predators, such as marine mammals, may be affected by fisheries even when the distributions of prey and predators do not overlap, driving species at the end of the food chain to the brink of extinction (Trites et al. 2006). Conservation efforts should be made locally to protect these species because this area suffers a high fishing pressure (ter Hofstede \& Dickey-Collas 2006, Christensen et al. 2004) and animals are constantly exposed to threats such as intensive fishing (Kenety 2001, Christensen et al. 2004), prey stock depletion (ter Hofstede \& Dickey- 
Collas 2006, Christensen et al. 2004), pollution and human disturbance (Colman et al. 2005). Conservation efforts should be unequivocally related to the local fishing policies, such as effective monitoring, control and surveillance of fisheries in the region (Atta-Mills et al. 2004); strengthening political interest to implement sustainable fisheries in NW Africa, because African leaders appear to be disregarding overfishing as a priority issue that needs to be addressed (NEPAD 2001); and lobbying the European Union and Asian countries, such as Japan and China, for policy reforms to minimize the impacts of European and Asian fishing fleets on NW African coastal marine resources.

Acknowledgements. Thanks are given to E. Grau, M. Gazo, S. Abdoulaye, E. Badosa, R. Samaranch, F. Aparicio, M. Cedenilla and J. Fernández Layna for assistance in the collection of material in the field; to L. Pazos and L. Barrio for their help in the lab; to the Director of the Parc National du Banc d'Arguin, L. Ould Yarba, and its scientific advisor, A. Araújo; to the Institut Mauritanien de Recherches Océanographiques et des Pêches for providing general assistance and providing access to their biological material; as well as to M. Vély, M. Dia and A. Ould Mohamed of the Centre National de l'Elevage et de Recherches Vétérinaires. The European Commission LIFE projects B4-3200/94/0000/D2 and B4-3200/96/510, a PRIC project of the Barcelona Zoo (Ayuntamiento de Barcelona), and the Government of Portugal funded the field and laboratory work. While this survey was carried out, A.M.P. was supported by a PhD scholarship from the Portuguese Foundation for Science and Technology of the Government of Portugal (SFRH/BD/32557/2006).

\section{LITERATURE CITED}

Ababouch L (2000) Potential of Listeria hazard in African fishery products and possible control measures. Int J Food Microbiol 62:211-215

Aguilar A (2000) Population biology, conservation threats, and status of Mediterranean striped dolphins (Stenella coeruleoalba). J Cetacean Res Manag 2:17-26

Anderson CNK, Hsieh CH, Sandin SA, Hewitt R and others (2008) Why fishing magnifies fluctuations in fish abundance. Nature 452:835-839

Atta-Mills J, Alder J, Sumaila UR (2004) The unmaking of a regional fishing nation: the case of Ghana and west Africa. Nat Resour Forum 28:13-21

Baumgartner MF (1997) The distribution of Risso's dolphin (Grampus griseus) with respect to the physiography of the northern Gulf of Mexico. Mar Mamm Sci 13:614-638

Bligh EG, Dyer WJ (1959) A rapid method of total lipid extraction and purification. Can J Biochem Physiol 37:911-917

> Bocherens H, Billiou D, Patou-Mathis M, Bonjean D, Otte M, Mariotti A (1997) Paleobiological implications of the isotopic signatures $\left({ }^{13} \mathrm{C},{ }^{15} \mathrm{~N}\right)$ of fossil mammal collagen in Scladina Cave (Sclayn, Belgium). Quat Res 48:370-380

Bunn SE, Loneragan NR, Kempster MA (1995) Effects of acid washing on stable isotope ratios of $\mathrm{C}$ and $\mathrm{N}$ in penaeid shrimp and seagrass: implications for food-web studies using multiple stable isotopes. Limnol Oceanogr 40: $622-625$

Cabana G, Rasmussen JB (1996) Comparison of aquatic food chains using nitrogen isotopes. Ecology 93:10844-10847
Cadenat J, Paraíso F (1957) Nouvelle observation de Sotalia teuszii (Cétacé, Delphinidé) sur les côtes du Sénégal. Bull Inst Fondam Afr Noire A 19:324-332

> Cardona L, Revelles M, Sales M, Aguilar A, Borrell A (2007) Meadows of the seagrass Posidonia oceanica are a relevant source of organic matter for adjoining ecosystems. Mar Ecol Prog Ser 335:123-131

Cardona L, Aguilar A, Pazos L (2009) Delayed ontogenic dietery shift and high levels of omnivory in green turtles (Chelonia mydas) from the NW coast of Africa. Mar Biol 156:1487-1495

Caut S, Angulo E, Courchamp F (2009) Variation in discrimination factors $\left(\delta^{15} \mathrm{~N}\right.$ and $\left.\delta^{13} \mathrm{C}\right)$ : the effect of diet isotopic values and applications for diet reconstruction. J Appl Ecol 46:443-453

Christensen V, Amorim P, Diallo I, Diouf $T$, Guénette $S$, Heymans JJ (2004) Trends in fish biomass off northwest Africa, 1960-2000. In: Moctar BA, Chavance P, Gascuel D, Vakily M, Pauly D (eds) Marine fisheries, ecosystems and societies: a half-century of change. Institut de Recherche pour le Developpement, Paris, and European Commission, Brussels, p 377-386

> Clarke MR, MacLeod N, Paliza O (1976) Cephalopod remains from the stomachs of sperm whales caught off Peru and Chile. J Zool 180:477-493

Colman JG, Gordon DM, Lane AP, Forde MJ, Fitzpatrick JJ (2005) Carbonate mounds off Mauritania, Northwest Africa: status of deep-water corals and implications for management of fishing and oil exploration activities. In: Freiwald A, Roberts JM (eds) Cold-water corals and ecosystems. Springer-Verlag, Berlin, p 417-441

> Das K, Beans C, Holsbeek L, Mauger G, Berrow SD, Rogan E, Bouquegneau JM (2003) Marine mammals from northeast Atlantic: relationship between their trophic status as determined by $\delta^{13} \mathrm{C}$ and $\delta^{15} \mathrm{~N}$ measurements and their trace metal concentrations. Mar Environ Res 56:349-365

> Davis RW, Ortega-Ortiz JG, Ribic CA, Evans WE and others (2002) Cetacean habitat in the northern oceanic Gulf of Mexico. Deep-Sea Res Part I 49:121-142

> De Stephanis R, Cornulier T, Verborgh P, Salazar Sierra J, Pérez Gimeno N, Guinet C (2008) Summer spatial distribution of cetaceans in the Strait of Gibraltar in relation to the oceanographic context. Mar Ecol Prog Ser 353: 275-288

> DeNiro MJ, Epstein S (1977) Mechanism of carbon isotope fractionation associated with lipid synthesis. Science 197: 261-263

> Drago M, Cardona L, Crespo EA, Aguilar A (2009) Ontogenic dietary changes in South American sea lions. J Zool 279: 251-261

Duguy R (1976) Contribution à l'étude des mammifères marins de la côte nord-ouest Afrique. Rev Trav Inst Pech Marit 39:321-332

- Emslie SD, Patterson WP (2007) Abrupt recent shift in $\delta^{13} \mathrm{C}$ and $\delta^{15} \mathrm{~N}$ values in Adélie penguin eggshell in Antarctica. Proc Natl Acad Sci USA 104:11666-11669

Feidi IH (1996) Fisheries development in the Arab world. Middle East Nat Environ Bull 103:388-406

Ferreira PS (1978) The economic potential of the oceans and African states. Oceans 10:411-416

Fontaine PM, Hammill MO, Barrette C, Kingsley MC (1994) Summer diet of the harbour porpoise (Phocoena phocoena) in the estuary and northern Gulf of St. Lawrence. Can J Fish Aquat Sci 51:172-178

- Forcada J, Hammond PS, Aguilar A (1999) Status of the Mediterranean monk seal $M$. monachus in the western Sahara and the implications of a mass mortality event. Mar 
Ecol Prog Ser 188:249-261

Ford JKB, Ellis GM, Balcomb KC (2000) Killer whales: the natural history and genealogy of Orcinus orca in British Columbia and Washington State. UBC Press, Vancouver Fry B (2006) Stable isotope ecology. Springer, New York, NY - Gazo M, Aguilar A (2005) Maternal attendance and diving behaviour of a lactating Mediterranean monk seal. Mar Mamm Sci 21:340-345

Gazo M, Aparicio F, Cedenilla MA, Layna JF, González LM (2000) Pup survival in the Mediterranean monk seal (M. monachus) colony at Cabo Blanco Peninsula (Western Sahara-Mauritania). Mar Mamm Sci 16:158-168

González AF, López A, Guerra A, Barreiro A (1994) Diets of marine mammals stranded on the northwestern Spanish Atlantic coast with special reference to Cephalopoda. Fish Res 21:179-191

González LM, Aguilar A, López-Jurado LF, Grau E (1997) Status and distribution of the Mediterranean Monk seal Monachus monachus on the Cabo Blanco Peninsula (Western Sahara-Mauritania) in 1993-1994. Biol Conserv 80:225-233

Hassani S, Antoine L, Ridoux V (1997) Diet of albacore, Thunnus alalunga, and dolphins, Delphinus delphis and Stenella coeruleoalba caught in the Northwest Atlantic albacore driftnet fishery: a progress report. J Northw Atl Fish Sci 22:119-123

Hobson KA (1999) Tracing origins and migration of wildlife using stable isotopes: a review. Oecologia 120:314-326

> Hobson KA, Clark RG (1992) Assessing avian diets using stable isotopes I: turnover of $\delta^{13} \mathrm{C}$ in tissues. Condor 94: 181-188

Hobson KA, Schell DM, Renouf D, Noseworthy E (1996) Stable carbon and nitrogen isotopic fractionation between diet and tissues of captive seals: implications for dietary reconstructions involving marine mammals. Can J Fish Aquat Sci 53:528-533

- Hobson KA, Sease JL, Merrick RL, Piatt JF (1997) Investigating trophic relationships of pinnipeds in Alaska and Washington using stable isotopes ratios of nitrogen and carbon. Mar Mamm Sci 13:114-132

> Jackson JBC, Sala E (2001) Unnatural oceans. Sci Mar 65: $273-281$

> Jackson JBC, Kirby MX, Berger WH, Bjorndal KA and others (2001) Historical overfishing and the recent collapse of coastal ecosystems. Science 293:629-638

Jouffre D, Inejih CA (2005) Assessing the impact of fisheries on demersal fish assemblages of the Mauritanian continental shelf, 1987-1999, using dominance curves. ICES J Mar Sci 62:380-383

Kenety B (2001) Three West African nations to ban EU fishing fleets. World News Inter Press News Service Agency. Available at www.afrol.com/Categories/Environment/env059_ eu_fisheries.htm

Lesage V, Hammill MO, Kovacs KM (2001) Marine mammals and the community structure of the Estuary and Gulf of St Lawrence, Canada: evidence from stable isotope analysis. Mar Ecol Prog Ser 210:203-221

Longhurst A (1998) The Atlantic Ocean: Atlantic coastal biomass-Eastern (Canary) coastal province (CNRY). In: Longhurst A (ed) Ecological geography of the sea. Academic Press, London, p 170-176

MacLeod CD, Weir CR, Pierpoint C, Harlan EJ (2007) The habitat preferences of marine mammals west of Scotland (UK). J Mar Biol Assoc UK 87:157-164

Maigret J (1980a) Données nouvelles sur l'ecologie du Sousa teuszii (Cetacea, Delphinidae) de la côte ouest africaine. Bull Inst Fondam Afr Noire A 42:619-633
Maigret J (1980b) Les mammifères marins des côtes de Mauritanie. Etat des observations en 1980. Bull Cent Natl Rech Oceanogr Pech 9:130-152

Maigret J (1981) Les mammifères marins des côtes de Mauritanie. 2. Rapport annuel des observations signalées en 1981. Bull Cent Natl Rech Oceanogr Pech 10:81-85

Maigret J, Trotignon J, Duguy R (1976) Observations de cétacés sur les côtes de Mauritania. ICES 1976/N:4-7. ICES, Copenhagen

Marchessaux D (1989) Researches sur la biologie, écologie et le status du phoque moine. PhD dissertation, GIS Posidonie, Marseille

Marchessaux D, Campredon P (1988) Ecologie des delphinides dans le Parc National du Banc d'Arguin, Republique Islamique de Mauritanie. Rapport Préliminaire. Parc National du Band d'Arguin, Nouakchott, Mauritania

Michener RH, Schell DM (1994) Stable isotope ratios as tracers in marine aquatic food webs. In: Lajtha $\mathrm{K}$, Michener $\mathrm{RH}$ (eds) Stable isotopes in ecology and environmental science. Blackwell, Oxford, p 138-157

> Minagawa M, Wada E (1984) Stepwise enrichment of ${ }^{15} \mathrm{~N}$ along food chains: Further evidence and the relation be tween $\delta^{15} \mathrm{~N}$ and animal age. Geochim Cosmochim Acta 48: $1135-1140$

- Myers RA, Worm B (2003) Rapid worldwide depletion of predatory fish communities. Nature 423:280-283

New Partnership for Africa's Development (NEPAD) (2001) NEPAD Strategic Framework, 37th Summit of the Organization of African Unity: July 2001. NEPAD Secretariat, Mirand Halfway House, Johannesburg

> Newsome SD, Koch PL, Etnier MA, Aurioles-Gamboa D (2006) Using carbon and nitrogen isotope values to investigate maternal strategies in Northeast Pacific otariids. Mar Mamm Sci 22:556-572

Ng JSS, Wai TC, Williams GA (2007) The effects of acidification on the stable isotope signatures of marine algae and molluscs. Mar Chem 103:97-102

Nieri M, Grau E, Lamarche B, Aguilar A (1999) Mass mortality of Atlantic spotted dolphins (Stenella frontalis) caused by a fishing interaction in Mauritania. Mar Mamm Sci 15: $847-854$

Ogawa N, Ogura N (1997) Dynamics of particulate organic matter in the Tamagawa Estuary and Inner Tokyo Bay. Estuar Coast Shelf Sci 44:263-273

Ostrom NE, Lien J, Macko SA (1993) Evaluation of the diet of Sowerby's beaked whale, Mesoplodon bidens, based on isotopic comparisons among north western Atlantic cetaceans. Can J Zool 71:858-861

Overholtz WJ, Waring GT (1991) Diet composition of pilot whales Globicephala sp. and common dolphins Delphinus delphis in the Mid-Atlantic Bight during spring 1989. Fish Bull 89:723-728

> Padial JM, Ibáñez C (2005) New records and comments for the Mauritanian mammal fauna. Mammalia 69:239-243

Pastor T (2010) Biología reproductiva y variabilidad genética en la foca monge del Mediterráneo (Monachus monachus). PhD dissertation, University of Barcelona, Barcelona

Pauly D, Christensen V, Dalsgaard J, Froese R, Torres FJR (1998a) Fishing down marine food webs. Science 279: 860-863

> Pauly D, Trites AW, Capuli E, Christensen V (1998b) Diet composition and trophic levels of marine mammals. ICES J Mar Sci 55:467-481

- Rendell L, Whitehead H, Escribano R (2004) Sperm whale habitat use and foraging success off northern Chile: evidence of ecological links between coastal and pelagic systems. Mar Ecol Prog Ser 275:289-295 
Robineau D, Vely M (1998) Les cétacés des côtes de Mauritanie (Afrique du Nord-Ouest). Particularités et variations spatio-temporelles de répartition: rôle de facteurs océanographiques. Rev Ecol Terre Vie 53:123-152

Rubenstein DR, Hobson KA (2004) From birds to butterflies: animal movements patterns and stable isotopes. Trends Ecol Evol 19:256-263

Saulitis E, Matkin C, Barrett-Lennard LG, Heise K, Ellis GM (2000) Foraging strategies of sympatric killer whale (Orcinus orca) populations in Prince William Sound, Alaska. Mar Mamm Sci 16:94-109

Segura I, Rocha-Olivares A, Flores-Ramírez S, Rojas-Bracho L (2006) Conservation implications of the genetic and ecological distinction of Tursiops truncatus ecotypes in the Gulf of California. Biol Conserv 133:336-346

Shumway CA (1999) Forgotten waters: freshwater and marine ecosystems in Africa. Strategies for biodiversity conservation and sustainable development. Global Printing, Vancouver

Skov H, Durinck J, Danielsen F, Bloch D (1995) Co-occurrence of cetaceans and seabirds in the Northeast Atlantic. J Biogeogr 22:71-88

Smeenk C, Leopold MF, Addink MJ (1992) Note on the harbour porpoise Phocoena phocoena in Mauritania, West Africa. Lutra 35:98-104

ter Hofstede R, Dickey-Collas M (2006) An investigation of seasonal and annual catches and discards of the Dutch pelagic freezer-trawlers in Mauritania, Northwest Africa. Fish Res 77:184-191

Editorial responsibility: Hans Heinrich Janssen, Oldendorf/Luhe, Germany
Tieszen LL, Boutton TW, Tesdahl KG, Slade NA (1983) Fractionation and turnover of stable carbon isotopes in animal tissues: implications for $\delta^{13} \mathrm{C}$ analysis of diet. Oecologia 57:32-37

Trites AW, Christensen V, Pauly D (2006) Effects of fisheries on ecosystems: Just another top predator? In: Boyd I, Wanless S, Camphuysen CJ (eds) Top predators in marine ecosystems. Cambridge University Press, Cambridge, p 11-27

Van Waerebeek K, André M, Sequeira M, Martín V and others (1999) Spatial and temporal distribution of the minke whale $B$. acutorostrata (Lacépède, 1804), in the southern northeast Atlantic Ocean and the Mediterranean Sea, with reference to stock identity. J Cetacean Res Manag 1:223-237

Van Waerebeek K, Barnett L, Camara A, Cham A and others (2004) Distribution, status, and biology of the Atlantic humpback dolphin, Sousa teuszii (Kükenthal, 1892). Aquat Mamm 30:56-83

Walker JL, Macko SA (1999) The correlation of diets of marine mammals with stable isotopic analyses of teeth. Mar Mammal Res 15:314-334

> Walters C, Kitchell JF (2001) Cultivation/depensation effects on juvenile survival and recruitment: implications for the theory of fishing. Can J Fish Aquat Sci 58:39-50

Wells S, Bleakley C (1995) West Africa, marine region 8. In: Kelleher G, Bleakley C, Wells S (eds) A global representative system of marine protected areas. Vol. II: Wider Caribbean, West Africa, and S. Atlantic. The World Bank, Washington, DC, p 43-69

Submitted: April 23, 2010; Accepted: August 26, 2010 Proofs received from author(s): October 7, 2010 